\title{
POTENTIAL OF JAVANESE TURMERIC ETHANOL EXTRACT IN INHIBITING STREPTOCOCCUS SANGUINIS AND PORPHYROMONAS GINGIVALIS BIOFILM FORMATION
}

\author{
REINA HUTAURUK, DEWI FATMA SUNIARTI*, WIDURINI DJOHAN
}

Department of Oral Biology, Faculty of Dentistry, Universitas Indonesia, Jakarta 10430 Indonesia. Email: dewisuniarti@yahoo.com

Received 28 October 2018, Revised 31 January 2019 and Accepted 01 February 2019

ABSTRACT

Objective: The purpose of the current study was to evaluate the potential of Javanese turmeric ethanol extract in the inhibition of the formation of Streptococcus sanguinis and Porphyromonas gingivalis biofilms, individually and in combination.

Methods: The concentration of P. gingivalis and S. sanguinis bacteria ranged from $0.5 \%$ to $25 \%$. Inhibition assay for biofilm formation was conducted on a 96-well plate using brain heart infusion (BHI) agar enriched with $0.2 \%$ sucrose at $37^{\circ} \mathrm{C}$ for $18 \mathrm{~h}$. After staining with $0.5 \%$ crystal violet, the optical density was measured at $490 \mathrm{~nm}$.

Results: Javanese turmeric can potentially inhibit the biofilm formation of S. sanguinis $\left(\mathrm{IC}_{50} 0.5 \%, \mathrm{IC}_{90} 15 \%\right.$ ) and P. gingivalis (IC $\left.\mathrm{IC}_{50} 15 \%\right)$ on single and dual species $\left(\mathrm{IC}_{50} 0.5 \%, \mathrm{IC}_{90} 15 \%\right)$.

Conclusion: Javanese turmeric has the potential to inhibit the formation of S. sanguinis and P. gingivalis biofilms.

Keywords: Javanese turmeric ethanol extract, Streptococcus sanguinis, Porphyromonas gingivalis, Biofilm, Inhibition

(c) 2019 The Authors. Published by Innovare Academic Sciences Pvt Ltd. This is an open access article under the CC BY license (http://creativecommons. org/licenses/by/4. 0/) DOI: http://dx.doi.org/10.22159/ijap.2019.v11s1.154

\section{INTRODUCTION}

Various synthetic mouthwashes with antimicrobial properties can be used for overcoming problems faced in the oral cavity, such as tooth disorders and tooth-supporting tissues [1]. However, certain unpleasant effects occur when using these products, such as an unpleasant taste in the mouth, dry mouth due to the alcohol content in the formulation, and irritation in the oral mucosa [1,2]. Another problem that arises is bacterial resistance against synthetic rinses in oral biofilms [2]. Considerable research has been conducted for discovering a plant-based antimicrobial agent that can solve the problems and unexpected effects of synthetic drugs.

Javanese turmeric (Curcuma xanthorrhiza Roxb.) is a medicinal plant selected, due to its great potential, to be studied and developed into herbal medicines in Indonesia. Part of the widely used Javanese turmeric plant is the rhizome, which contains starches, curcuminoid minerals, minerals, essential oils, and fatty oils. Essential oils in the Javanese turmeric rhizome contain xanthorrhizol, B-curcumin, androgen receptor curcumin, camphor, and germacrene [3]. Xanthorrhizol isolated from Javanese turmeric reportedly has antimicrobial activity against some pathogenic bacteria of the oral cavity [4] and is a specific component that is found only in volatile oil of Javanese turmeric and not in the essential oils of other Curcuma groups $[4,5]$.

Oral biofilm occurs when bacteria in the oral cavity form a community of bacteria and attach to a surface. Oral biofilm is reportedly the cause of several diseases in the oral cavity, such as caries and periodontal disease [6]. Several phases of oral biofilm formation exist, including the formation of the pellicle on the surface of the tooth, the removal of microorganisms and reversible attachment, bacterial colonization and irreversible attachment, bacterial coaggregation/coadhesion, and biofilm ripening [6]. Bacteria that continue to grow in an oral biofilm can lead to reduced sensitivity toward antibiotics and antimicrobial agents and cause problems in the oral cavity. One of the disorders caused in the oral cavity by pathogenic bacteria such as Porphyromonas gingivalis is periodontitis, which in the later stages can cause the loss of tooth adhesion.
A study by Rukayadi and Hwang (2000) reported that xanthorrhizol obtained from Javanese turmeric ethanol extract had antibacterial activity. Minimum inhibitory concentration (MIC) of xanthorrhizol against Streptococcus sanguinis was $4 \mu \mathrm{g} / \mathrm{ml}$, and minimum bactericidal concentration (MBC) was $8 \mu \mathrm{g} / \mathrm{ml}$. While against $P$. gingivalis, minimum inhibitory concentration (MIC) and minimum inhibitory concentration (MBC) were $32 \mu \mathrm{g} / \mathrm{ml}$ [7]. The results showed that xanthorrhizol was more effective against $S$. sanguine bacteria than against $P$. gingivalis. The purpose of the present study was to evaluate the potential of Javanese turmeric ethanol extract in the inhibition of the formation of S. sanguinis and $P$. gingivalis biofilms as individual and combination biofilms.

\section{MATERIALS AND METHODS}

Preparation of $S$. sanguinis and $P$. gingivalis bacterial concentrations of $10^{-5}$

The research samples used are $S$. sanguinis American type culture cell (ATCC) strain 10556 and P. gingivalis ATCC strain 33277 obtained from the bacteria stock of Oral Biology Laboratory, Faculty of Dentistry, Universitas Indonesia.

This study used a bacterial concentration of $10^{-5}$. The bacterial concentration was prepared by making suspensions of $P$. gingivalis and S. sanguinis bacteria from $10^{-1}$ to $10^{-5}$ dilutions. Eppendorf tubes with successive numbers were prepared for bacterial suspensions from $10^{-1}$ to $10^{-5}$. Each Eppendorf tube was filled with a $900-\mu \mathrm{l} \mathrm{BHI} \mathrm{liquid.} \mathrm{Next,} \mathrm{a}$ $100-\mu \mathrm{l}$ bacterial parent solution was introduced to the first Eppendorf tube, and then homogenized with a vortex mixer for producing a suspension with a bacterial concentration of $10^{-1}$. The same method was performed with the second Eppendorf tube for obtaining a bacterial suspension with a concentration of $10^{-2}$. This continued until the suspension reached a concentration of $10^{-5}$.

Preparation of various concentrations of Javanese turmeric ethanol extract

In a macroscopic view, the ethanol extract of turmeric was a concentrated powder. For facilitating manipulation, the ethanol 
extract of Javanese turmeric was centrifuged at $3000 \mathrm{rpm}$ for $10 \mathrm{~min}$, forming four layers. The first layer was used as the test material in the experiment. In this study, the concentrations of Javanese turmeric ethanol extracts identified were $0.25 \%, 0.5 \%, 1 \%, 5 \%, 10 \%, 20 \%$, and $25 \% ; 10 \%$ dimethyl sulfoxide (DMSO) concentration was used as a solvent.

\section{Preparation of control groups}

The negative controls in this study were $100 \mu \mathrm{l}$ of $S$. sanguinis and $P$. gingivalis single bacteria with concentrations of $10^{-5}$, and the combination of both bacteria at the volume of $50 \mu \mathrm{l}$ each (total solution $100 \mu \mathrm{l}$ ). Positive controls were $100 \mu \mathrm{l}$ of $S$. Sanguinis and P. gingivalis single bacteria with concentrations of $10^{-5}$, and combinations of both bacteria exposed to 100- $\mu$ l chlorhexidine (CHX) $0.2 \%$ and $10 \%$ DMSO solvent. A total of $10 \mu \mathrm{l}$ each of positive and negative control solutions were planted in $\mathrm{BHI}$ agar and incubated for $48 \mathrm{~h}$ at $37^{\circ} \mathrm{C}$.

Determining minimal inhibitory response and minimum bactericidal concentration of Javanese turmeric ethanol extract on $S$. sanguinis and $P$. gingivalis

Minimal inhibitory response [8]

MIC was determined by microtiter broth dilution method. The suspension of bacteria in as much as $100 \mu \mathrm{l}$ of $10^{-5}$ concentration was added to 96-well plates according to the group. Next, $100 \mu \mathrm{l}$ of Javanese turmeric ethanol extract with various concentrations was identified. The Javanese turmeric ethanol extract showed different colors at each concentration; therefore, a sample blank was made at every concentration and added by the medium of BHI broth. All 96-well plates were placed in an anaerobic jar and incubated for $48 \mathrm{~h}$ at $37^{\circ} \mathrm{C}$ in an anaerobic atmosphere. After the incubation period, the absorbance was read on a microplate reader with a wavelength of $450 \mathrm{~nm}$. The value of inhibition was expressed in percent using the following formula [9]:

\%inhibition $=\left(1-\left(\frac{\text { OD sample }- \text { OD sample-blank }}{\text { OD control }- \text { OD control-blank }}\right)\right) \times 100$

\section{Minimum Bactericidal Concentration [8]}

In addition to the confirmation of the results from the readings of the microplate reader, $1 \mu \mathrm{l}$ of each evaluated group was injected into the BHI agar and incubated for $48 \mathrm{~h}$ at $37^{\circ} \mathrm{C}$ in an anaerobic atmosphere. After removal from the anaerobic jar, bacterial colonies were calculated. The lowest concentrations of unidentified Javanese turmeric ethanol extracts that did not show bacterial growth were defined as MBC.

Determining the percentage of inhibition of $S$. sanguinis and $P$ gingivalis as individual and combination biofilms

Exposure of Javanese turmeric ethanol extract to an individual or combination biofilm formation [10]

In each well of the 96-well plates, $100 \mu \mathrm{l}$ of BHI broth was added along with $0.2 \%$ sucrose with a bacterial suspension of $10^{-5}$ concentration to be tested. Next, $100 \mu \mathrm{l}$ of Javanese turmeric ethanol extract was added at various concentrations to each group. On the positive controls, $100-\mu \mathrm{l}$ CHX $0.2 \%$ was added to each well, while on the negative controls, the wells were not treated. This procedure was performed 3 times; then the 96 -well plate was incubated for $18 \mathrm{~h}$ at $37^{\circ} \mathrm{C}$ in an anaerobic atmosphere. Inhibitory values of biofilm formation determined if the biofilm inhibition was $>50 \%$ compared with the negative control (MBEC50).

\section{Crystal violet test [11]}

The required amount of $0.5 \%$ crystalline violet solution was created in a 15-ml centrifuge tube. Well plate that has been incubated was rinsed once with 100- $\mu$ l PBS solution. A total of $100 \mu$ l of violet crystalline solution was added to each well; then the well plate was incubated for $15 \mathrm{~min}$ at $37^{\circ} \mathrm{C}$. Every well was rinsed twice with sterile aquadest, and $100 \mu \mathrm{l}$ of $96 \%$ ethanol solution was added to each well, and they were then incubated for $15 \mathrm{~min}$ at $37^{\circ} \mathrm{C}$. Optical density (OD) values were read on a microplate reader at $490 \mathrm{~nm}$.

\section{RESULTS}

Determination of MIC and MBC of Javanese turmeric ethanol extract against $S$. sanguinis and $P$. gingivalis bacteria

In the present study, it was determined that the MIC value of Javanese turmeric ethanol extract against $S$. sanguinis was $5 \%$ (Table 1) because, at that concentration, the percentage value of inhibition reached $>90 \%$. The higher the identified concentration, the higher the percentage of inhibition of $S$. sanguinis bacteria. MBC value was set at $15 \%$ because the percentage of inhibition reached $100 \%$ at that concentration. These results were confirmed by inoculating the $1 \mu \mathrm{l}$ of bacteria that were exposed to Javanese turmeric ethanol extracts identified in agar medium, resulting in no bacterial colony growth.

Table 1 shows the decrease in the percentage of inhibition of $P$. gingivalis. The MIC and MBC of $P$. gingivalis against Javanese turmeric ethanol extract were not identified because the percentage of inhibition did not reach $90 \%$. Further confirmation was done by inoculating the $1 \mu \mathrm{l}$ of bacteria exposed to Javanese turmeric ethanol extract identified in agar medium, resulting in bacterial colony growth in all treatment groups.

\section{Potential inhibitors of $S$. sanguinis biofilm formation}

A qualitative test inhibiting biofilm formation on the basis of violet crystals showed an increased percentage of inhibition of $S$. sanguinis biofilm formation correlating with increasing concentrations of Javanese turmeric ethanol extract. At the concentration of $0.5 \%(69.75 \pm 1.07)$ of Javanese turmeric, ethanol extract was identified as inhibiting the formation of $S$. sanguinis biofilm (MBEC50 value). A 15\% concentration $(96.38 \pm 3.13)$ of Javanese turmeric ethanol extract showed that there was no significant difference in the percentage of $S$. sanguinis biofilm inhibition with the positive control (MBEC90 value) (Table 2). In the correlation test, the concentration Javanese turmeric ethanol extract with percentages of S. sanguinis biofilm inhibition showed a significant result $(\mathrm{p}<0.025)$ and positive directional correlation (Pearson correlation $=0.905$ ). The result of linear regression analysis showed that the presentation of biofilm inhibition with the increasing concentration of Javanese turmeric ethanol extract showed a significant relationship $(\mathrm{p}<0.05)$ and strong correlation (R-squared $=0.819$ ). The regression equation was $Y=54.837+7.248 \mathrm{X}$ ( $Y=$ Percentage value of biofilm inhibition, $7.248=$ Constant, $X=$ Increased concentration of Javanese turmeric ethanol extract).

\section{Potential inhibitors of $\boldsymbol{P}$. gingivalis biofilm formation}

A qualitative test inhibiting biofilm formation on the basis of violet crystal test showed that the percentage of inhibition of Javanese turmeric ethanol extract against $P$. gingivalis biofilm correlated with increasing concentrations. The inhibition of $P$. gingivalis biofilm formation began at a concentration of $15 \%$ (52.42 \pm 1.49$)$; it was thus expressed as MBEC50, but no percentage of inhibition reached a value $>90 \%$; therefore, no MBEC90 value could be determined. There was a decrease in the percentage of inhibition at 25\% concentration with a value below MBEC50 (42.39 \pm 1.73$)$. ANOVA test results in Table 3 showed a significant difference in the percentage of inhibition of Javanese turmeric ethanol extract observed with negative control and also positive control $(\mathrm{p}<0.05)$. The potential of Javanese turmeric ethanol extract for inhibiting the formation of $P$. gingivalis biofilm was identified, but its potential was not equivalent to the positive control.

In the correlation test, the concentration of Javanese turmeric ethanol extract identified with percentages of $P$. gingivalis biofilm inhibition showed a significant result $(\mathrm{p}<0.025)$ and positive directional correlation (Pearson Correlation=0.811). The result of linear regression analysis showed that the presentation of biofilm inhibition with increasing concentration of Javanese turmeric ethanol extract showed a significant relationship $(\mathrm{p}<0.05)$ and strong correlation (R-squared=0.658). The regression equation was $\mathrm{Y}=15.321+7.535 \mathrm{X}$ ( $\mathrm{Y}=$ Percentage value of biofilm inhibition, 15.321=Constant and $\mathrm{X}=$ Concentration of Javanese turmeric ethanol extract). 
Table 1: Inhibition of Javanese turmeric ethanol extract against S. sanguinis and P. gingivalis

\begin{tabular}{|c|c|c|}
\hline $\begin{array}{l}\text { Concentrations of ethanol extracts of Javanese } \\
\text { turmeric and control }\end{array}$ & $\begin{array}{l}S \text {. sanguinis } \% \text { biofilm } \\
\text { Inhibition } \pm \text { Standard deviation }\end{array}$ & $\begin{array}{l}\text { P. gingivalis } \% \text { Biofilm } \\
\text { Inhibition } \pm \text { Standard deviation }\end{array}$ \\
\hline Negative control & 0 & 0 \\
\hline Positive control & $101.44 \pm 1.01$ & $100.08 \pm 0.05$ \\
\hline $0.25 \%$ & $85.3 \pm 1.02$ & $81.08 \pm 1.23$ \\
\hline $0.5 \%$ & $88.88 \pm 9.44$ & $78.58 \pm 0.23$ \\
\hline $1 \%$ & $84.65 \pm 3.34$ & $77.68 \pm 2.68$ \\
\hline $5 \%$ & $92.96 \pm 0.65^{\bullet}$ & $73.85 \pm 2.11$ \\
\hline $15 \%$ & $103.74 \pm 2.02^{0}$ & $70.90 \pm 4.63$ \\
\hline $20 \%$ & $101.50 \pm 0.07$ & $70.18 \pm 4.87$ \\
\hline $25 \%$ & $101.47 \pm 0.24$ & $72.04 \pm 1.58$ \\
\hline DMSO 10\% & $22.93 \pm 5.94$ & $17.07 \pm 1.19$ \\
\hline
\end{tabular}

•MIC; ${ }^{\circ}$ MBC. S. sanguinis: Streptococcus sanguinis, P. gingivalis: Porphyromonas gingivalis

Table 2: Potential of Javanese turmeric ethanol extract for inhibiting $S$. sanguinis biofilm formation

\begin{tabular}{|c|c|c|c|}
\hline $\begin{array}{l}\text { Concentrations of ethanol extracts of Javanese } \\
\text { turmeric and control }\end{array}$ & $\begin{array}{l}\% \text { Biofilm } \\
\text { Inhibition } \pm \text { Standard deviation }\end{array}$ & $\begin{array}{l}\text { p value against negative } \\
\text { control* }\end{array}$ & $\begin{array}{l}\text { p value against positive } \\
\text { control* }\end{array}$ \\
\hline Negative control & 0 & - & $* 0.000$ \\
\hline Positive control & $109.9 \pm 8.15$ & $* 0.000$ & - \\
\hline $0.5 \%$ & $69.75 \pm 1.07$ & $* 0.000$ & $* 0.000$ \\
\hline $1 \%$ & $66.94 \pm 3.02$ & $* 0.000$ & $* 0.000$ \\
\hline $5 \%$ & $72.45 \pm 1.02$ & $* 0.000$ & $* 0.000$ \\
\hline $10 \%$ & $72.88 \pm 2.45$ & $* 0.000$ & $* 0.000$ \\
\hline $20 \%$ & $103.04 \pm 2.87$ & $* 0.000$ & 0.626 \\
\hline $25 \%$ & $105.35 \pm 8.68$ & $* 0.000$ & 0.932 \\
\hline
\end{tabular}

One-way ANOVA test result $* \mathrm{p}<0.05 ;{ }^{\bullet} \mathrm{MBEC}_{50} ;{ }^{\circ} \mathrm{MBEC}_{90}$. S. sanguinis: Streptococcus sanguinis

Table 3: Potential of Javanese turmeric ethanol extract to inhibits P. gingivalis biofilm

\begin{tabular}{|c|c|c|c|}
\hline $\begin{array}{l}\text { Concentrations of ethanol extracts of Javanese } \\
\text { turmeric and control }\end{array}$ & $\begin{array}{l}\% \text { Biofilm } \\
\text { Inhibition } \pm \text { Standard deviation }\end{array}$ & $\begin{array}{l}\text { p value against negative } \\
\text { control* }\end{array}$ & $\begin{array}{l}\text { p value against positive } \\
\text { control* }\end{array}$ \\
\hline Negative control & 0 & - & ${ }^{*} 0.000$ \\
\hline Positive control & $96.40 \pm 0.72$ & $* 0.000$ & - \\
\hline $0.5 \%$ & $20.08 \pm 2.22$ & $* 0.005$ & $* 0.000$ \\
\hline $1 \%$ & $38.36 \pm 1.55$ & $* 0.000$ & $* 0.000$ \\
\hline $5 \%$ & $41.57 \pm 0.63$ & $* 0.000$ & ${ }^{*} 0.000$ \\
\hline $10 \%$ & $39.20 \pm 1.18$ & $* 0.000$ & $* 0.000$ \\
\hline $20 \%$ & $63.38 \pm 2.57$ & $* 0.000$ & $* 0.000$ \\
\hline $25 \%$ & $42.39 \pm 1.73$ & $* 0.000$ & $* 0.000$ \\
\hline
\end{tabular}

One-way ANOVA test result * $\mathrm{p}<0.05 ;{ }^{\bullet} \mathrm{MBEC}_{50}{ }^{\text {P. }}$ gingivalis: Porphyromonas gingivalis

Table 4: Potential of Javanese turmeric ethanol extract for inhibiting $S$. sanguinis and P. gingivalis biofilms

\begin{tabular}{|c|c|c|c|}
\hline $\begin{array}{l}\text { Concentrations of ethanol extracts of Javanese } \\
\text { turmeric and control }\end{array}$ & $\begin{array}{l}\% \text { Biofilm } \\
\text { Inhibition } \pm \text { Standards deviation }\end{array}$ & $\begin{array}{l}\text { p value against negative } \\
\text { control* }\end{array}$ & $\begin{array}{l}\text { p value against positive } \\
\text { control* }\end{array}$ \\
\hline Negative control & 0 & - & $* 0.000$ \\
\hline Positive control & $110.16 \pm 1.66$ & $* 0.000$ & - \\
\hline $0.5 \%$ & $86.75 \pm 1.63$ & $* 0.000$ & $* 0.000$ \\
\hline $1 \%$ & $86.78 \pm 0.46$ & ${ }^{*} 0.000$ & $* 0.000$ \\
\hline $5 \%$ & $82.55 \pm 0.85$ & ${ }^{*} 0.000$ & $* 0.000$ \\
\hline $10 \%$ & $94.57 \pm 2.76$ & ${ }^{*} 0.000$ & $* 0.000$ \\
\hline $20 \%$ & $112.65 \pm 4.46$ & $* 0.000$ & 0.885 \\
\hline $25 \%$ & $105.10 \pm 2.61$ & ${ }^{*} 0.000$ & 0.167 \\
\hline
\end{tabular}

One-way ANOVA test result * $<<0.05$. S. sanguinis: Streptococcus sanguinis, P. gingivalis: Porphyromonas gingivalis

Potential of Javanese turmeric ethanol extract for inhibiting $S$ sanguinis and $P$. gingivalis biofilm formation

An increase in the percentage of inhibition of $S$. sanguinis and $P$. gingivalis combination biofilm was in line with the increased concentration of Javanese turmeric ethanol extract. The inhibition of $S$. sanguinis and $P$. gingivalis combination biofilm formation began at $0.5 \%$ concentration $(86.75 \pm 1.63)$ (MBEC50 value). The result of ANOVA test in Table 4 showed that the percentage of combination biofilm inhibition by Javanese turmeric ethanol extract identified from $15 \%$ concentration $(110.99 \pm 1.36)$ did not significantly differ from the percentage of control biofilm inhibition ( $p>0.05)$; it was thus determined to be MBEC90. 
In the correlation test between the increase of Javanese turmeric ethanol extract concentration and the increase of biofilm inhibition percentage, a significant result was obtained $(\mathrm{p}<0.025)$, and it was strongly correlated (Pearson Correlation=0.826). The result of linear regression analysis showed that the percentage of inhibition of the combination biofilm with increasing concentration of Javanese turmeric ethanol extract showed a significant relationship $(\mathrm{p}<0.05)$ and strong correlation (R-square=0.682). The regression equation was $\mathrm{Y}=77.743+4.829 \mathrm{X}(\mathrm{Y}=$ Percentage value of biofilm inhibition, 77.743=Constant, and $\mathrm{X}=$ Javanese turmeric ethanol extract increase in concentration).

\section{DISCUSSION}

Gram-negative bacteria have longer growth time in BHI medium than Gram-positive bacteria; therefore, the incubation time and exposure to Javanese turmeric ethanol extract are differentiated for both bacteria [12]. S. sanguinis bacteria are incubated for $48 \mathrm{~h}$, while P. gingivalis bacteria are incubated for $72 \mathrm{~h}$ in an anaerobic atmosphere. The MIC value of $S$. sanguinis bacteria is determined at the concentration of $5 \%$, and MBC value is determined at the concentration of $15 \%$. When $S$. sanguinis bacteria that are exposed to Javanese turmeric ethanol extract are injected into a growing medium agar, the number of colonies at concentrations of $5-10 \%$ is decreased compared with negative controls. At concentrations of $15-25 \%$, there is no formation of colonies. The MIC values in this study are different than those noted in the research conducted by Ajrina Busri (2013), who reported a MIC value of Javanese turmeric ethanol extract against $S$. sanguinis bacteria of $0.5 \%$. This may be due to differences in the xanthorrhizol content, phytochemicals, and methods used in this study and previous studies.

This study cannot assign MIC and MBC values to P. gingivalis bacteria. With an increasing concentration of Javanese turmeric ethanol extract, no percentage of inhibition reaches a value of $90 \%$. The reading of the $\mathrm{OD}$ value with the microplate reader is confirmed by growing bacteria on the agar medium, and the colonies are formed in all concentration groups. These results indicate that $P$. gingivalis bacteria are more resistant to Javanese turmeric ethanol extract than are S. sanguinis bacteria. A study conducted by Wibowo (2012) reported that $P$. gingivalis was not as sensitive to Javanese turmeric ethanol extract when compared with $S$. sanguinis, and the study was unable to establish MIC and MBC values in $P$. gingivalis [13]. This may be due to the bacterial cell wall of $P$. gingivalis which has a more complex peptidoglycan structure, lipopolysaccharides, and lipoproteins than S. sanguinis bacteria [6]

The primary active ingredient of Javanese turmeric ethanol extract is xanthorrhizol. In its chemical bond, xanthorrhizol has a phenol group that plays a significant role in the antibacterial activity. Phenol can cause the process of protein denaturation on the cell walls of bacteria, causing the bacteria to die. In addition, phenolic compounds are sensitive to enzyme oxidation and quickly form complexes with proteins. At low concentrations, phenols will damage the cytoplasmic membrane and cause leakage of the cell nucleus; whereas, at high concentrations, the denaturation process occurs by changing the permeability of cell walls and coagulation of proteins, resulting in the lysis of the bacterial cell membrane $[13,14]$. The mechanism of action of an antibacterial agent can be observed from the correlation between the concentration that initiates bacteriostatic and bactericidal effects and physiological and biochemical changes of the bacteria. For CHX, the interaction with bacteria includes ionic bonds; whereas, in phenolic compounds, the characteristics are physical [15].

The activity of antibacterial agents is more effective during bacterial cleavage because the bacterial cell wall components will be used for the synthesis, causing the cell wall to become thin $[16,17]$. Thin cell walls allow antibacterial agents to more easily penetrate through the cell wall. The time of cleavage and the development of $S$. sanguinis bacteria are faster when compared with $P$. gingivalis bacteria, explaining why
Javanese turmeric ethanol extract is more sensitive to $S$. sanguinis bacteria than to $P$. gingivalis bacteria $[12,18]$.

The results of this study show that Javanese turmeric ethanol extract has potential as an inhibitor of $S$. sanguinis biofilm formation as measured by the percentage of biofilm inhibition compared with control MBEC50. $S$. sanguinis bacteria are identified at $0.5 \%$ concentration of Javanese turmeric ethanol extract, while MBEC90 values are obtained at 15\% concentration. Javanese turmeric ethanol extract of $15 \%$ concentration has the same potential of inhibiting the growth of $S$. sanguinis biofilm as CHX. The results of the correlation test show a strong correlation between the concentration of Javanese turmeric ethanol extract and a decrease in the percentage of biofilm inhibition of S. sanguinis bacteria.

In a linear regression test for measuring the effect of concentration of Javanese turmeric ethanol extract to the percentage of inhibition, the equation is $Y=54.837+7.248 X$. This equation shows that each concentration of Javanese turmeric ethanol extract is identified, followed by $7.248 \%$ increase in the percentage of biofilm inhibition. The higher the concentration of Javanese turmeric ethanol extract, the higher the ability to inhibit the formation of S. sanguinis biofilm.

An increased percentage of $S$. sanguinis inhibition is seen along with increased concentration due to the antibacterial activity of xanthorrhizol capable of destroying bacterial cell walls. With the destruction of the bacterial membrane, the ability to attach the bacteria to the biofilm is lost due to bacterial lysis. $S$. sanguinis bacteria attach to the tooth surface using a pili that bind to a salivary protein, especially amylase, so that it can contribute to form biofilms on surfaces coated by saliva [14]. S. sanguinis bacteria are pioneer bacteria and bridge the attachment of late colonizer bacteria, so that when $S$. sanguinis cells undergo other bacterial attachment, lysis will be disrupted. This causes the failure of biofilm formation $[6,11]$.

MBEC50 P. gingivalis bacteria are obtained at a Javanese turmeric ethanol extract concentration of $15 \%$, but this research cannot determine the concentration for obtaining MBEC90. The increased concentration of Javanese turmeric ethanol extract does not coincide with the increased percentage of $P$. gingivalis biofilm inhibition due to a decrease in the percentage of inhibition at $25 \%$ concentration (43.35 \pm 8.96$)$. Javanese turmeric ethanol extract has the potential to inhibit the formation of $P$. gingivalis biofilm at $15 \%$ concentration, but its potency is not equivalent to that of CHX. The correlation test shows no strong correlation between Javanese turmeric ethanol extract concentration and the percentage of biofilm inhibition.

In a linear regression test for measuring the effect of the concentration of Javanese turmeric ethanol extract to the percentage of inhibition, the equation is $Y=15.321+7.535 X$. However, the linear regression test also shows that the relationship between increasing the concentration of Javanese turmeric ethanol extract with biofilm formation inhibition is not strong. This equation shows that each concentration of Javanese turmeric ethanol extract is identified, followed by a $7.535 \%$ increase in the percentage of biofilm inhibition.

P. gingivalis bacteria are obligate anaerobic, asaccharolytic, and sensitive to acids, requiring hemin, and Vitamin K for growth [19]. Javanese turmeric ethanol extract assumedly blocks the formation of $P$. gingivalis biofilm but does not kill $P$. gingivalis bacteria. The reduction of bacterial inhibition is not noted at $25 \%$ concentration. One possibility is that the unidentified Javanese turmeric ethanol extract has a double effect on $P$ gingivalis bacteria, that is, low concentrations are antibacterial in nature, but high concentrations increase $P$. gingivalis viability. This study has not been able to elucidate why there is a decrease in inhibition percentage at high concentrations; thus, further research is required.

Oral biofilms such as dental plaques are a community of different bacterial species and can experience harmonious relationships with the host. However, the presence of groups of Gram-negative bacteria, 
such as excessive $P$. gingivalis, can be associated with the initiation and progression of periodontal disease [20]. In the growth of biofilm, the required interaction between bacteria can be synergistic or antagonistic. The synergistic interactions include enzyme fragment complementation, food chain, coadhesion, cell-to-cell signaling, and gene transfer. On the contrary, the interactions of antagonists include bacteriocin, hydrogen peroxide, organic acid, low $\mathrm{pH}$, and nutritional competition [6].

At the beginning of colonization, $P$ gingivalis must survive in aerobic conditions in supragingival plaque. To persist in this condition, $P$. gingivalis bacteria use adhesion mechanisms with fimbriae for early colonizer bacteria [19]. The bacterial adhesion mechanism of $P$. gingivalis with pioneer bacterial groups will lead to bacterial interactions, making the biofilm less acidic and allowing $P$. gingivalis bacteria to grow $[20,21]$. An in vitro study has reported that $P$. gingivalis bacteria can be attached to the surface of a $S$. sanguinis bacterium. The attachment of $P$. gingivalis bacteria in the $S$. sanguinis biofilm is mediated by protein-to-protein interactions as well as the femoral minor antigen role of $P$. gingivalis and streptococcal polypeptide of $S$. sanguinis [22].

The results of this study revealed that Javanese turmeric ethanol extract inhibits the formation of $S$. sanguinis and $P$. gingivalis combination biofilm, as measured by the percentage of biofilm inhibition compared with the control. MBEC50 is obtained at $0.5 \%$ concentration, and MBEC90 is obtained at $15 \%$ concentration. The correlation test shows that there is a strong correlation between the increased concentration of Javanese turmeric ethanol extract and increased percentage of combination biofilm inhibition. At a concentration of $15 \%$, a statistical test with one-way ANOVA shows that Javanese turmeric ethanol extract is a potential inhibitor of the growth of $S$. sanguinis and $P$. gingivalis combination biofilm equivalent to $\mathrm{CHX}$.

In a linear regression test for measuring the effect of Javanese turmeric ethanol extract concentration to the percentage of inhibition obtained, the equation is $\mathrm{Y}=77.743+4.829 \mathrm{X}$ ( $\mathrm{Y}=$ Percentage value of biofilm inhibition, 77.743=Constant, and $\mathrm{X}=$ Concentration of Javanese turmeric ethanol extract). This equation shows that each concentration of Javanese turmeric ethanol extract is identified, followed by a $4.829 \%$ increase in the percentage of biofilm inhibition. The higher the concentration of Javanese turmeric ethanol extract, the higher the inhibition of $S$. sanguinis and P. gingivalis combination biofilm.

The inhibition of combination biofilm formation caused by exposure to Javanese turmeric ethanol extract is similar to the $0.5 \%$ inhibition of single $S$. sanguinis biofilm formation. The inhibition of formation of $S$. sanguinis and $P$. gingivalis combination biofilm may occur because Javanese turmeric ethanol extract can prevent the occurrence of early interaction between $S$. sanguinis with $P$. gingivalis to form the biofilm. In addition, interactions between bacteria can be antagonistic, which results in the production of hydrogen peroxide in the early days of biofilm formation and the existence of nutritional competition between S. sanguinis and P. gingivalis [21].

\section{CONCLUSION}

Javanese turmeric ethanol extract effectively inhibits the in vitro growth of $S$. sanguinis and $P$. gingivalis biofilm, either individually or in combination. Javanese turmeric ethanol extract has the potential to work against the growth of $S$. sanguinis biofilms, and its combination with $P$. gingivalis has an effect equivalent to $\mathrm{CHX}$.

\section{CONFLICTS OF INTEREST}

The author reports no conflicts of interest.

\section{REFERENCES}

1. Aspalli S, Shetty VS, Devarathnamma MV, Nagappa G, Archana D, Parab $\mathrm{P}$, et al. Evaluation of antiplaque and antigingivitis effect of herbal mouthwash in treatment of plaque induced gingivitis: A randomized, clinical trial. J Indian Soc Periodontol 2014; 18:48-52.

2. Solmaz G, Korachi M. Inhibition and disruption properties of chlorhexidine gluconate on single and multispecies oral biofilm. Jundishapur J Microbiol 2013;6:61-6.

3. Indonesian Agency of Food and Drugs Administration. National movement of drinking Curcuma xanthorrhiza. Clin Microbiol Rev 2005;12:400-4.

4. Rukayadi Y, Hwang JK. In vitro activity of Xanthorrhizol against Streptococcus mutans Biofilms. Lett Appl Microbiol 2006;42:400-4.

5. Kasiran K. Increased supply of natural medicinal raw materials sourced from Javanese turmeric: Study on the production of Javanese turmeric (Curcuma xanthorrhiza) through the use of different seed sizes. Bul Penelit Sist Kesehat 2008;11:270-5.

6. Marsh PD, Martin MV. Oral Microbiology. $5^{\text {th }}$ ed. London: Churchill Livingstone Elsevier; 2011. p. 30-85.

7. Tu Y, Huang W, Pan Z, Hu H, Chen H. Effect of Streptococcus sanguinis/Porphyromonas gingivalis single and combined biofilms upon platelet aggregation. Oral Dis 2012;18:586-94.

8. Lima BA, Lira SP, Kossuga M, Goncalves R, Berlinck R, Kamiya R. Halistanol sulfate A and rodriguesines A and B are antimicrobial and antibiofilm agents against the cariogenic bacterium Streptococcus mutans. Rev Bras Farmacogn 2014;24:651-9.

9. Hertiani T, Pratiwi SU, Irianto ID, Adityaningrum D, Pranoto B. Effect of Indonesian medicinal plants essential oils on Streptococcus mutans biofilm. Maj Farm Indones 2011;23:174-81.

10. Quave CL, Plano LR, Pantuso T, Bennett BC. Effects of extracts from Italian medicinal plants on planktonic growth, biofilm formation and adherence of methicillin-resistant Staphylococcus aureus. J Ethnopharmacol 2008;118:418-28.

11. O'Toole GA, Kolter R. Initiation of biofilm formation in pseudomonas fluorescens WCS365 proceeds via multiple, convergent signalling pathways: A genetic analysis. Mol Microbiol 1998;28:449-61.

12. Minhas T, Greenman J, Schaffer A. Effects of mucin, haemoglobin and collagen on the maximum specific growth rate, biomass and hydrolytic enzyme production of Porphyromonas gingivalis in continuous culture. Microb Ecol Health Dis 1991;4:311-9.

13. Wibowo M, Deasywaty D, Usia T. Antimicrobial and identification of active compound Curcuma xanthorrhiza Roxb. Int J Basic Appl Sci 2012;12:69-78.

14. Wilson S, Dick H. Topley and Wilson's Principle of Bacteriology, Virology, and Immunity. $7^{\text {th }}$ ed. London: Edward Arnol Ltd; 1984. p. 84.

15. Greenberg $M$, Dodds $M$, Tian $M$. Naturally occurring phenolic antibacterial compounds show effectiveness against oral bacteria by a quantitative structure-activity relationship study. J Agric Food Chem 2008;56:11151-6.

16. Campos FM, Couto JA, Figueiredo AR, Tóth IV, Rangel AO, Hogg TA, et al. Cell membrane damage induced by phenolic acids on wine lactic acid bacteria. Int J Food Microbiol 2009;135:144-51.

17. Harold C, Thomas D. Medical Microbiology. $4^{\text {th }}$ ed. Galveston: The University of Texas Medical Branch at Galveston; 1996.

18. Kemp CW, Robrish SA, Curtis MA, Sharer SA, Bowen WH. Application of a competition model to the growth of Streptococcus mutans and Streptococcus sanguis in binary continuous culture. Appl Environ Microbiol 1983;45:1277-82.

19. Bostanci N, Belibasakis GN. Porphyromonas gingivalis: An invasive and evasive opportunistic oral pathogen. FEMS Microbiol Lett 2012;333:1-9.

20. Labrecque J, Bodet C, Chandad F, Grenier D. Effects of a highmolecular-weight cranberry fraction on growth, biofilm formation and adherence of Porphyromonas gingivalis. J Antimicrob Chemother 2006;58:439-43.

21. Kreth J, Zhang Y, Herzberg MC. Streptococcal antagonism in oral biofilms: Streptococcus sanguinis and Streptococcus gordonii interference with Streptococcus mutans. J Bacteriol 2008;190:4632-40.

22. Stinson MW, Safulko K, Levine MJ. Adherence of Porphyromonas (Bacteroides) gingivalis to Streptococcus sanguis in vitro. Infect Immun 1991;59:102-8 